Revista Eletrônica Geografar, Curitiba, v. 2, Resumos do VI Seminário Interno de Pós-Graduação em Geografia, p. 09-09. Junho/2007

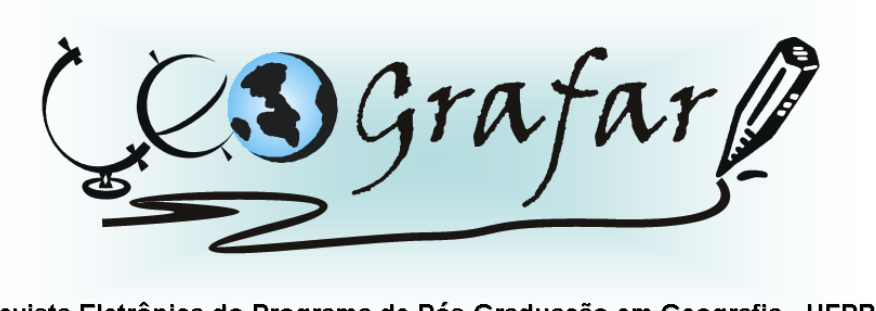

Revista Eletrônica do Programa de Pós-Graduação em Geografia - UFPR

\title{
O CLIMA URBANO DE CIDADES DE PEQUENO E MÉDIO PORTE: UMA ANÁLISE DA INTERAÇÃO LOCAL-REGIONAL EM IRATI E GUARAPUAVA/PR
}

\section{APARECIDO RIBEIRO DE ANDRADE ${ }^{1}$}

Atualmente os problemas na vida do homem estão aumentando, principalmente aqueles originados da contaminação do ar, do solo e da água, além do esgotamento de recursos naturais e o aumento de doenças próprias do estilo de vida estressante - notadamente nos centros urbanos - falta de moradia, de infra-estrutura básica, etc. Os centros urbanos de pequeno e médio porte também concentram população, atividades econômicas e, conseqüentemente, problemas ambientais associados e amplificados nos últimos anos, da mesma forma que os centros urbanos de grande porte. Entretanto, sua manifestação apresenta uma escala de abrangência diferenciada. A preocupação com o entendimento dos atributos físicos de um dado ambiente caracterizou a evolução das sociedades, mas encontra-se cada vez menos presente no atual estilo de vida. Há uma crescente falta de ajuste entre a população, seu ambiente, as atividades econômicas predominantes e o estágio de desenvolvimento atual da sociedade. O clima urbano se apresenta como matéria de grande interesse para qualquer pesquisador, mas de forma mais acentuada para o geógrafo, ao tentar entender a relação sociedade/natureza. No decorrer do trabalho a hipótese a ser perseguida é a distinção climática entre duas cidades (diferentes em sua estrutura), mas que estão na mesma área de abrangência, em uma região com a característica geomorfológica extremamente peculiar (front - sopé - e reverso de uma cuesta), buscando assim, o alcance de resultados consistentes para a definição da dinâmica climática nas escalas meso e topoclimática. A metodologia a ser utilizada é o Sistema Clima Urbano (MONTEIRO, 1976), mas não sozinha, ou seja, autores como Ana Maria Brandão, Francisco Mendonça e Inês Danhi-Oliveira, deverão ser considerados, além de outros que pesquisam e pesquisaram na mesma linha. O objetivo final será colaborar para a caracterização climática da região, buscando uma ferramenta mais eficaz para um possível planejamento urbano e geo-ecológico.

Palavras-chave: clima urbano, planejamento urbano, escala climática

${ }^{1}$ Doutorando em Geografia - UFPR - email: apaandrade@gmail.com Orientadora: INÊS MORESCO DANNI-OLIVEIRA 